\title{
ANALISIS KINERJA KEUANGAN TERHADAP LABA PERUSAHAAN LEMBAGA PENGEMBANGAN TEKNOLOGI TEPAT GUNA MALINDO DI KECAMATAN BAEBUNTA KABUPATEN LUWU UTARA
}

\author{
Aisyah \\ Email : institusi@stiem.ac.id \\ Program Studi Manajemen Sekolah Tinggi Ilmu Ekonomi Muhammadiyah Palopo
}

\begin{abstract}
Abstrak
Penelitian ini bertujuan untuk mengetahui kinerja keuangan dalam menghasilkan laba perusahaan lembaga pengembangan teknologi tepat guna malindo dikecamatan baebunta kabupaten luwu utara. Metode pengumpulan data dilakukan dengan cara melakukan penelitian lapangan,dan penelitian kepustakaan kemudian analisis rasio keuangan dengan jumlah sampel sebanyak 3 tahun dari tahun 2014 - 2016. Hasil penelitian menunjukkan bahwa return on asset (ROA) LPTTG Malindo kecamatan baebunta, kabupaten luwu utara mengalami peningkatan disebabkan terjadinya peningkatan penjualan selama setahun pada tahun 2015 dengan nilai signifikasn $0,354 \%$. Dan pada tahun 2014 hanya mencapai 0,087\% sedangkan ditahun terakhir 2016 hanya mencapai 0,158\%. Yang artinya rasio ini belum mampu mengelola seluruh aktifa untuk menghasilkan laba bersih.
\end{abstract}

Kata kunci : Rasio likuiditas, Rasio aktivitas, ROA

\section{PENDAHULUAN}

SetiapLaba atau keuntungan merupakan salah satu tujuan utama perusahaan dalam menjalankan aktivitasnya. Laba yang diperoleh perusahaan akan digunakan untuk berbagai kepentingan, laba akan digunakan untuk meningkatkan kesejahteraan perusahaan tersebut atas jasa yang diperoleh. Begitu pula dengan pengukuran kinerja keuangan perusahaan diperlukan untuk menentukan keberhasilan dalam mencapai tujuan tersebut. Pengukuran kinerja keuangan berdasarkan laporan keuangan banyak dilakukan dengan menggunkana alat ukur kinerja yang kadang berbeda. Untuk menilai seberapa jauh efektifitas operasi perusahaan dalam mencapai tujuanya diperlukan metode pengukuran tertentu. Salah satu cara untuk mengetahui kinerja keuangan suatu perusahaan dapat dilakukan dengan menganalisis laporan keuangannya.

LPTTG Malindo sebagai salah satu industri pangan kering yang ada di kecamatan baebunta, sudah tentu mempunyai laporan keuangan, laporan keuangan merupakan salah satu informasi untuk menganalisa keadaan perusahaan dimasa akan datang, laporan keuangan diharapkan dapat memberi informasi tentang keadaan perusahaan dari hasil-hasil usaha yang telah dicapai secara kuantitatif pada semua pihak yang berkepentingan dengan perusahaan itu. Informasi akan menjadi komoditi yang sangat penting saat ini, sebab setiap pengambilan keputusan harus didasari pada informasi yang akurat.
Dilihat dari data perusahaan LPTTG Malindo bahwa penjualan mengalami peningkatan dan penurunan, pada tahun 2014 - 2016 penjualan mengalami penurunan sebesar 36.000.000. hal ini yang menjadi alasan penelitian untuk meneliti LPTTG Malindo. Untuk mengetahui lebih lanjut bagaimana kondisi dan kinerja keuangan suatu perusahaan beserta perkembangan suatu perusahaan tersebut dengan menggunakan suatu alat analisis rasio keuangan maka diketahuilah keadaan perusahaan tersebut. Atas dasar permasalahan inilah peneliti bermaksud untuk melakukan pengujian lebih lanjut, maka peneliti merasa terdorong untuk melakukan penelitian dengan judul: Analisis Kinerja Keuangan terhadap Laba perusahaan Lembaga Pengembangan Teknologi Tepat Guna Malindo. Berdasarkan latar belakang masalah tersebut diatas, maka masalah pokok dalam penelitian ini adalah bagaimanakah kinerja keuangan dalam menghasilkan laba perusahaan lembaga pengembangan teknologi tepat guna malindo. Adapun tujuan penelitian ini yaitu untuk mengetahui Kinerja Keuangan dalam menghasilkan Laba perusahaan Lembaga Pengembangan Teknologi Tepat Guna Malindo.

\section{TINJAUAN PUSTAKA}

\section{Pengertian Kinerja Keuangan}

Sukhemi, (2007:23) "untuk memahami terlebih dahulu apa itu kinerja. Istilah kinerja kerap dihubungkan dengan kondisi keuangan perusahaan. Kinerja dapat diartikan sebagai prestasi yang dicapai perusahaan dalam suatu periode tertentu yang 
mencerminkan tingkat kesehatan perusahaan tersebut". Jumingan, (2011:239) "kinerja merupakan prestasi yang dicapai perusahaan baik menyangkut aspek keuangan, aspek pemasaran, aspek perhimpunan dana, dan penyaluran dana, aspek teknologi, maupun aspek sumber daya manusianya". Fahmi (2012:2) kinerja keuangan merupakan gambaran dari pencapaian keberhasilan perusahaan dapat diartikan sebagai hasil yang telah dicapai atas berbagai aktivitas yang telah dilakukan. Dapat dijelaskan bahwa kinerja keuangan adalah suatu analisis yng dilakukan untuk melihat sejauh mana perusahaan telah melaksanakan dengan menggunakan aturan - aturan pelaksanaan keuangan secara baik dan benar. Menurut Bambang Riyanto (2001:327) kinerja keuangan adalah "mengadakan interprestasi atau analisis terhadap laporan finansiil dari perusahaan yang bersangkutan".

\section{Pengertian Laba}

Pengertian laba dapat dibedakan menjadi dua, yakni pengertian secara ekonomi murni maupun pengertian secara akuntansi. Laba dalam ilmu ekonomi dapat diartikan sebagai keuntungan yang didapat oleh seorang investor dalam suatu kegiatan bisnisnya.hal initentu sudah dikurangi dengan biaya operasional yang ada di suatu bisnis yang dijalankan. Hal ini akan memberikan kemudahan dalam memahami laba atau yang secara umum dikenal dengan kata keuntungan. Sementara itu, laba menurut ilmu akuntansi didefinisiksn sebagai selisih antara harga penjualan dengan biaya yang dikeluarkan pada saat produksi. Menurut Mahmud M.Hanafi (2010:32), menyatakan bahwa " laba merupakanukuran keseluruhan prestasi perubahan, yang didefinisikan sebagai berikut :laba = penjualan - baiaya”. Menurut kasmir (2011: 303) jenisjenis laba yaitu 1) laba kotor (gross profit margin) artinya laba yang diperoleh sebelum dikurangi biayabiaya yang menjadi beban perusahaan. Artinya laba keseluruhan yang pertama kali perusahaan peroleh; 2) laba bersih (net profit) merupakan laba yang telah dikurangi biaya-biaya yang merupakan beban perusahaan dalam suatu periode tertentu termasuk pajak.

\section{Pengertian Rasio Keuangan}

Rasio keuangan merupakan kegiatan membandingkan angka-angka yang ada dalam laporan keuangan dengan membagi satu angka dengan angka yang lainnya. Menurut James C. Van Horne, dalam bukunya kasmir. Rasio keuangan merupakan indeks yang menghubungkan dua angka akuntansi dan diperoleh dengan membagi satu angka dengan angka yang lainnya. Rasio keuangan digunakan untuk mengavaluasi kondisi keuangan dan kinerja keuangan, dari hasil rasio keuangan ini akan kelihatan kondisi kesehatan perusahaan yang bersangkutan. Menurut Toto Pribadi (2008), rasio keuangan secara khusus digunakan oleh investor atau kreditor dalam keputusaninvestasi dan penyaluran dana dengan cara membandingkan antara rasio perusahaan dengan industri.

\section{METODE}

Data kuantitatif, yaitu data yang diperoleh dari perusahaan yang diteliti dalam bentuk angkaangka dan dapat digunakan untuk pembahasan lebih lanjut. Data primer yaitu dapa yang diperoleh langsung dari perusahaan yang memerlukan pengelolaan lebih lanjut untuk disesuaikan dengan bahasan skripsi ini, antara lain data keuangan, yaitu neraca dan rugi laba. Populasi adalah kumpulan dari semua kemungkinan orang-orang, benda mati dan ukuran lain yang menjadi objek perhatia atau kumpulan seluruh objek yang menjadi perhatian (suhardi dan purwanto 2013:7). Sampel adalah suatu bagian dari populasi tertentu yang menjadi perhatian (suhardi dan purwanto, 2013:7), dan yang menjadi sampel dalam penelitian ini yaitu laporan kinerja keuangan dari perusahaan Lembaga Pengembangan Teknologi Tepet Guna Malindo di Salulemo Kecamatan Baebunta Tahun 2014 - 2016. Untuk mengetahui kinerja keuangan Lembaga Pengembangan Teknologi Tepat Guna Malindo terhadap laba maka digunakan metode analisis rasio keuangan dengan rumus sebagai berikut:

\section{Rasio likuiditas}

Rasio lancar, yaitu rasio untuk mengukur kemampuan perusahaan dalam membayar kewajiban financial jangka pendek dengan menggunakan aktiva lancar.

$$
\text { Rasio lancar }=\frac{\text { Asset lancar }}{\text { Utang lancar }} \times 100 \%
$$

Rasio tunai, yaitu rasio untuk mengukur kemampuan perusahaan dalam membayar kewajiban financial jangka pendek dengan menggunakan aktiva lancar yang lebih likuid.

$$
\text { Rasio tunai }=\frac{\text { Asset lancar }- \text { persediaan }}{\text { Utang lancar }} \times 100 \%
$$

\section{Rasio aktivitas}

Total assets turn over, rasio untuk mengukur tingkat perputaran total aktiva terhadap penjualan.

$$
\text { Total asset turn over }=\frac{\text { Penjualan bersih }}{\text { Total asset }} \times 100 \%
$$

Workin capital turn over, rasio untuk mengukur tingkat perputaran modal kerja bersih (aktiva lancar hutang lancar) terhadap penjualan selama suatu periode siklus kas dari perusahaan.

$$
\text { Workin capital turn over }=\frac{\text { Net sales }- \text { HPP }}{\text { Net sales }}
$$

Inventory turn over, rasio untuk mengukur tingkat efisiensi pengelolaan perputaran persediaan yang 
dimiliki terhadap penjualan. Semakin tinggi rasio ini akan semakin baik dan menunjukkan pengelolaan persediaan yang efisien.

$$
\text { Inventory turn over }=\frac{\text { Cost of goods sold }(\mathrm{HPP})}{\text { Average inventiry }} \times 100 \%
$$

Adapun rasio yang akan digunakan untuk mengetahui laba perusahaan Lembaga Pengembangan Teknologi Tepat Guna Malindo yaitu Return on asset (ROA) adalah salah satu bentuk dari rasio profitabilitas untuk mengukur kemampuan perusahaan dalam menghasilkan laba dengan menggunakan total aktiva yang ada dan setelah biaya - biaya modal (biaya yang digunakan mendanai aktiva dikeluarkan dari analisis). Menurut Sudana (2011), menunjukkan kemampuan perusahaan dengan menggunakan seluruh aktiva yang dimiliki untuk menghasilkan laba setelah pajak, dimana rasio ini penting bagi pihak manajemen untuk mengevaluasi efektifitas dan efisiensi manajemen perusahaan dalam mengelola setiap aktiva perusahaan, yang berarti besar ROA berarti semakin efisien penggunaan aktiva perusahaan, dan sebaiknya.

$$
\text { Return on asset }(\mathrm{ROA})=\frac{\text { Laba bersih setelah pajak }}{\text { Total aktiva }} \times 100 \%
$$

\section{HASIL DAN PEMBAHASAN}

\section{Hasil Penelitian}

Permasalahan yang dibahas dalam penelitian ini adalah bagaimanakah kinerja keuangan dalam menghasilkan laba perusahaan lembga pengembangan teknologi tepat guna malindo. Data yang dianalisis adalah laporan keuangan yang terdiri dari neraca dan laporan rugi laba tahun $2014-2016$.

Tabel 1. Neraca Keuangan LPTTG Malindo Kecamatan Baebunta Tahun 2014 - 2016 (Dalam Rp)

\begin{tabular}{|c|c|c|c|}
\hline Tahun & Aktiva lancar & Aktiva tetap & Total aktiva \\
\hline 2014 & 56.500 .000 & 150.350 .000 & 206.850 .000 \\
\hline 2015 & 60.800 .000 & 144.850 .000 & 205.650 .000 \\
\hline 2016 & 77.150 .000 & 146.650 .000 & 223.800 .000 \\
\hline
\end{tabular}

Sumber Data: laporan keuangan LPTTG Malindo

Adapun laporan laba rugi pada LPTTG Malindo di kecamatan Baebunta tahun 2014 - 2016 adalah sebagai berikut:

Tabel 2. Laporan Laba Rugi LPTTG Malindo di Kecamatan Baebunta Tahun 2014 - 2016 (Dalam Rp)

\begin{tabular}{|c|l|c|r|r|}
\hline \multirow{2}{*}{ No } & \multirow{2}{*}{ keterangan } & \multicolumn{3}{|c|}{ Tahun } \\
\cline { 3 - 5 } & Penjualan & 144.000 .000 & \multicolumn{1}{|c|}{$\mathbf{2 0 1 5}$} & $\mathbf{2 0 1 6}$ \\
\hline 1. & Seno0.000 & 180.000 .000 \\
\hline 2. & Saldo awal & 100.000 .000 & 95.000 .000 & 90.000 .000 \\
\hline 3. & $\begin{array}{l}\text { Biaya } \\
\text { produksi }\end{array}$ & 140.000 .000 & 117.000 .000 & 124.100 .000 \\
\hline 4. & Persediaan & 20.800 .000 & 23.650 .000 & 30.850 .000 \\
\hline 5. & $\begin{array}{l}\text { Laba sebelum } \\
\text { pajak }\end{array}$ & 39.150 .000 & 98.100 .000 & 55.900 .000 \\
\hline 6. & Biaya usaha & 17.800 .000 & 12.300 .000 & 14.100 .000 \\
\hline 7. & Laba bersih & 18.147 .500 & 72.930 .000 & 35.530 .000 \\
\hline
\end{tabular}

Sumber Data LPTTG Malindo
Untuk mengetahui kinerja keuangan LPTTG Malindo (Lembaga Pengembangan Teknologi Tepet Guna Masyarakat Indonesia ) di Kecamatan Baebunt, hasil perhitungan disajikan dalam bentuk sebagai berikut:

\section{Hasil Perhitungan Analisis Data}

Tabel 3. Rekapitulasi Hasil Analisis Rasio Keuangan pada LPTTG Malindo di Kecamatan Baebunta

\begin{tabular}{|l|l|c|c|c|c|}
\hline \multirow{2}{*}{ No } & \multirow{2}{*}{ INDIKATOR } & \multicolumn{2}{|c|}{ TAHUN } & \multirow{2}{*}{ KET } \\
\cline { 3 - 5 } & & 2014 & 2015 & 2016 & \\
\hline \multirow{3}{*}{1.} & Likuiditas & & & & \\
\cline { 2 - 5 } & 1.1 rasio lancar & $0,528 \%$ & $0,544 \%$ & $0,576 \%$ & Naik \\
\cline { 2 - 5 } & 1.2 rasio cepat & $0,334 \%$ & $0,332 \%$ & $0,346 \%$ & Naik \\
\hline \multirow{4}{*}{2.} & Aktivitas & & & & \\
\cline { 2 - 6 } & 2.1 perputaran total aktiva & $0,695 \mathrm{kali}$ & $1,050 \mathrm{kali}$ & $0,804 \mathrm{kali}$ & Turun \\
\cline { 2 - 6 } & 2.2 perputaran modal kerja & $-5,776 \mathrm{kali}$ & $0,616 \mathrm{kali}$ & $-2,492 \mathrm{kali}$ & Turun \\
\cline { 2 - 5 } & 2.3 perputaran persediaan & $5,041 \mathrm{kali}$ & $4,985 \mathrm{kali}$ & $4,022 \mathrm{kali}$ & Turun \\
\hline 3. & Laba & & & & \\
\hline & Return on Asset (ROA) & $0,087 \%$ & $0,354 \%$ & $0,158 \%$ & Turun \\
\hline
\end{tabular}

Sumber : LPTTG Malindo, data diolah

\section{Pembahasan \\ Rasio likuiditas}

Likuiditas adalah kemampuan keuangan perusahaan (asset lancar) untuk membayar kewajiban yang segera harus dipenuhi. Yang termasuk rasio likuiditas adalah : rasio lancar (curren ratio), rasio tunai (quick ratio), cash ratio. Sedangkan yang saya gunakan adalah : rasio lancar (curren ratio), rsio tunai (quick ratio).

\section{Curren ratio (rasio lancar)}

Perhitungan menunjukkan bahwa rasio lancar pada tahun terakhir hanya mencpai 0, 576\% ini berarti bahwa rasio lancar LPTTG Malindomampu menjamin hutang lancarnya sebanyak 0,576 kali, tahun 2015 dimana perhitunganya hanya mencapai 0,544 kali sedangkan tahun 2014 perhitungan hanya mencapai 0,528 kali sehingga dapat disimpulkan bahwa kinerja keuangan LPTTG Malindo selama tiga tahun terakhir ini dapat memperlihatkan kinerja keuanganya dengan kategori baik.

\section{Quick ratio (rasio tunai)}

Mengacu pada hasil analisis data melalui tabel 3, dapat dijelaskan bahwa rasio cepat pada LPTTG Malindo pada tahun terakhir mencapai 0,346 kali yang sesuai standar, maka aktiva lancar yang cepat cair sebesar $0,346 \%$. Sedangkan tahun 2015 hanya mencapai 0,332 . Perhitungan ditahun 2014 hanya mencapai 0,334 kali. Hal ini mengindikasikan bahwa kinerja keuangan LPTTG Malindo selama tiga tahun terakhir berada pada kategori kinerja "baik".

\section{Rasio aktivitas}

Aktivitas adalah rasio untuk mengukur seberapa efektif perusahaan dalam mendapatkan sumber daya yang dimilikinya. Sedangkan rasio yang saya gunakan dalam penelitian ini adalahtotal assetturn over, workin capital turn over dan inventori turn over.

\section{Total asset turn over}

Pada hasil analisis data melalui tabel 3, dapat dijelaskan bahwa total asset turn over pada LPTTG 
Malindo pada tahun 2016 sebesar 0,804 kali, dan pada tahun 2015 sebesar 1,050 kali, sedangkan ditahun 2014 sebesar 0,695 kali, maka semakin tinggi tingkat perputaran total aktiva terhadap penjualan akan semakin bagus. Hal ini menunjukkan bahwa kinerja keuangan LPTTG Malindo selama tiga tahun terakhir berada pada kategori kinerja tidak bagus.

\section{Working capital turn over}

Hasil analisis data pada tabel 3, menunjukkan bahwa rasio working capital turn over pada LPTTG Malindo pada tahun 2014 hanya sebesar $-5,776$ kali, dan pada tahun 2015 sebesar 0,616 kali, sedangkan pada tahun 2016 sebesar $-2,492$ kali, artinya rasio ini tidak mampu mengukur perputaran modal kerja sehingga dapat disimpulkan bahwa kinerja keuangan LPTTG Malindo selama tiga tahun memperlihatkan kinerja keuangan yang sangat tidak memuaskan

\section{Inventori turnover}

Rasio ini menunjukkan bahwa inventory turn over pada LPTTG Malindo pada tahun 2016 hanya sebesar 4, 022 kali, dan pada tahun 2015 seberas 4,985 kali, sedangkan tahun 2014 mencapai sebesar 5, 041 kali artinya rasio ini tidak mampu mengukur pengelolaan persediaan yang dimiliki tiga tahun terakhir ini sehingga dapat disimpulkan bahwa kinerja keuangan LPTTG Malindo selama tiga tahun memperlihatkan kinerja keuangan yang kurang bagus.

Return on Asset (ROA)

Dari hasil analisis tabel 3, menunjukkan bahwa return on asset pada LPTTG Malindopada tahun 2016 sebesar $0,158 \%$, sedangkan pada tahun 2015 sebesar 0,354\%, dan pada tahun 2014 hanya mencapai sebesar $0,087 \%$ yang artinya rasio ini belum mampu mengelola seluruh aktifa untuk menghasilkan laba bersih sehingga dapat disimpulkan bahwa kinerja keuangan LPTTG Malindoselama tiga tahun memperlihatkan kinerja keuangan yang tidak bagus. Berdasarkan dari pembahasan penelitian, maka hipotesis yang diajukan bahwa kinerja keuangan di tahun 2014 - 2016 pada LPTTG Malindo di kecamatan Baebunta Kabupaten Luwu Utara, dan mengalami peningkatan hanya ditahun 2014 ditolak karna hanya tahun 2015 kinerja keuangan LPTTG Malindo mengalami peningktan.

\section{SIMPULAN}

\section{Simpulan}

Berdasarkan hasil analisis yang telah dikemukakan pada Bab sebelumnya, maka dapat ditarik kesimpulan sebagai berikut 1) pada tahun 2015 return on asset (ROA) LPTTG Malindo kecamatan Baebunta kab, Luwu utara mengalami peningkatan disebabkan terjadinya peningkatan penjualan selama setahun; 2) terjadi penurunan Return on asset pada tahun 2014 2016 disebabkan karna hasil penjualan yang menurun pada tahun 2014 - 2016.

\section{Saran}

Mengacu pada kesimpulan diatas, maka dapat diajukan beberapa saran sebagai berikut 1) perusahaan sebaiknya meningkatkan kinerja keuanganya dan berupaya meningkatkan laba prusahaan untuk tahun - tahun berikutnya; 2) perusahaan sebaiknya berupaya meningkatkan produksi penjualanya dalam rangka peningkatan kinerja keuangan tahun - tahun berikutnya.

\section{DAFTAR PUSTAKA}

Aditya Rieskan Wahdine. (2010) . Analisis Likuiditas dan Rentabilitas Untuk Mengukur Kinerja Keuangan Pada PT Kedawu Setia Industrial Tbk. Proposal skripsi program studi menejemen.

Agustinus (2005), Analisis Kinerja Keuangan Berdasarkan Rasio Keuangan Early Warning System (EWS) pada PT. Asuransi Ramayana Tbk. jakarta.( penelitian terdahulu)

Astuti, Dewi. 2004, Manajemen Keuangan Perushaan . jakarta : galia indonesia

Dewi Asmaranii.bloqspot co.id/2014/12/Analisis Laporan Keuangan

Global Lavebookx. Bloqspot. Co.id/2014/01/ Pengertian Kinerja Keuangan dan Pengukuran

Horne, James C Van John M. Wachowicz ,jr 2005 Prinsip-prinsipManajemen Kuangan, edisi ke 12 , buku 1 , alih bahasa: heru sutojo, salemba empat, jakarta

https

://Dwiermayanti. Wardpress.com/2011/06/10/analisis rasio keuangan ( diakses Tgl 17 Februari 2017)

https : // id. M. Wiki pedia. Org/ wiki/ Laporan Keuangan (diakses Tgl 17 Februari 2017)

https: // Ardra. Biz/ Ekonomi/ Ekonomi Keuangan Manajemen Keuangan / AnalisisRasio Keuangan Perusahaan. (diakses Tgl 17 Februari 2017)

http.// Hobi Akuntansi. Blogspot. Co id/ 2015/04/ Penyajian LaporanKeuanganMenurut PSAK, (diakses Tgl 17 Februari 2017)

http :// Ngapak. Net/ Laporan Keuangan, (diakses Tgl 17 Februari 2017)

http://pengertian definisi.com/Pengertian LabaDefenisi Ahli dan Unsur-unsur Laba

http://www.kajian pustaka.com/2013/09/Pengertian Unsur-unsur dan Jenis-jenis Laba.html

http://www.facebook.com/pages/Addad Danuartas blog.

Ikatan Akuntan Indonesia, 2004. Standar Akuntansi Keuangan, salemba empat. Jakarta

Indah widiyahningsih 2010, pengaruh rasio lancar,perputaran total aktiva,tingkat pengembalian dari aktiva,tingkat 
pengembaliandari modal,dan perputaran persediaan terhadap pertumbuhan laba perusahaan manufaktur industri makanan dan minuman.

Ima andriyani 2015, pengaruh rasio keuangan terhadap pertumbuhan laba pada perusahaan pertambangan yang terdaftar di bursa efek indonesia.

Jumingan (2011), Analisis Laporan Keuangan.PT Bumi Aksara, Jln sawo raya, jakarta.

Kasmir (2010), Analisis Laporan Keuangan, jakarta rajawali pers

Kasmir (2010), Pengantar Manajemen Keuangan, jakarta : kencana.

Lianto 2013 : Penilaian Kinerja Keuangan Perusahaan Menggunakan Analisis Du Poin Pada Perusahaan PT HN dan PT Gudang Garam.

Novita p. Hamidu 2013, pengaruh kinerja keuangan terhadap pertumbuhan laba pada perbankan di BEI.

Panji Widya Rasmi, ADLN Perpustakaan Universitas Airlangga.

Puspitasari 2012, AnalisisLaporan Keuangan Guna Mengukur Kinerjakeuangan PT Astra Internasional Tbk.

Suharyadi, Purwanto. 2013 Statistika : Untuk Ekonomi dan Keuangan Modern edisi 2Penerbit. Jakarta : salemba empat.

Thessalonica S.F.Supit, Welly.A. Areros, Johny.R.E.Tampi. Analisis Kinerja Keuangan pada PT Astra Internasional,Tbk.(Jurnal)

Tips Serba Serbi bloqspot co id /2015/03 : Pengertian Kinerja Keuangan menurut para shli (Diakses 17 Februari)

www.Akutt. com / 2013 / 11 / Definisi Neraca Kaporan keuangan arti. (Diakses 17 Februari 2017)

www.Ekonomi. Com/ 2017/ 01/Analisis Rasio Keuangan.htm!?m:I, (Diakses 17 Februari 2017)

www.Kembar. Pro Analisis Laporan Laba Rugi ,( Diakses 1 Januari 2017)

www.Landasan teori.com/ 2015/10/Pengertian Laporan Laba RugiPerusahaan, (Diakses 1 Januari 2017) 